INDEPENDENT JOURNAL OF MANAGEMENT \& PRODUCTION (IJM\&P)

http://www.ijmp.jor.br

v. 8, n. 5, Special Edition IFLOG 2016

ISSN: 2236-269X

DOI: 10.14807/ijmp.v8i5.595

\title{
ANALYSIS OF DEMAND IN THE IMPORTATION PROCESS FOR THE TRADE OF INDIVIDUAL PROTECTION EQUIPMENT
}

\author{
Tatiane Chiles Toledo \\ Instituto Federal de São Paulo campus Suzano, Brazil \\ E-mail: tati_cht@hotmail.com \\ Geisiane Ferreira Silva \\ Instituto Federal de São Paulo campus Suzano, Brazil \\ E-mail: geisifs@hotmail.com \\ Wagner Roberto Garo Junior \\ Instituto Federal de São Paulo campus Suzano, Brazil \\ E-mail: wagner.garo@ifsp.edu.br
}

Submission: 30/12/2016

Accept: 12/01/2017

\section{ABSTRACT}

The organizations maintain excessive inventories as a way to anticipate the customer's need, taking, this way, competitive advantage. On the other hand, the lack of stocks can stop assembly lines; change the production schedule; increase costs and harm the marketing planning. However, there are costs in relation to these inventories; therefore, set an appropriate policy stock management is a critical factor for the success of a company, in addition to obtaining sustainable competitive advantage in the long term. Considered by many as the basis for managing the supply chain, inventory management depends on clear definitions for the following questions: how much to ask, when to ask, how much to keep in stock and where to find the stock. Therefore, there must be a balance in relation to demand and stock supply. Increased market competitiveness forces companies to lower their stock costs and may result in loss of orders due to lack of product. This paper describes the process of forecasting demand, and the methods of analysis forecasting as a tool to reduce costs by simulating the methods of demand forecasting in order to improve the level of stock. Thus, a case study was elaborated in the ABC Company, which acts in the imported PPE business for analyzing the process and simulating the techniques of demand forecasting.

[http://creativecommons.org/licenses/by/3.0/us/]

Licensed under a Creative Commons Attribution 3.0 United States License 
The results presented in the case study were satisfactory actually observed divergence between the processes applied before the company and applied studies directly on demand obtained with this assertiveness in the forecast.

Keywords: Demand forecast; Logistics; Supply Chain; Stock

\section{INTRODUCTION}

The reduction of inflation in Brazil finalized a phase of revenue for the organizations that was often the valuation of stocks (KRIEGER, 2002). Thus, a thorough examination of inventory costs proved to be of fundamental importance to the financial health and development of organizations. The main function of inventories is to ensure the availability of products according to the company's operational characteristics and to absorb the present uncertainties, monitoring everything that has an impact on the level of inventories.

According to Slack et al. (2007), the stock exists to compensate for the differences in the rhythm between supply and demand of material resources, that is, if the supply of any item occurred when demanded, the item would never need to be stocked.

Based on this concept, a case study was carried out, with the purpose to apply other methods of forecasting demand. Thus, we analyze the continuous stock balances of $A B C$ Company in a way that allows the execution of applications of forecast models of demand enabling verification by the models and methods used to improve results accuracy of inventory levels.

According to Ballou (2006), demand forecasting is imperative for the company in all departments, as it provides parameters for supply and control. Therefore, realizing this view, the decision was made to analyze the demand forecasting process in the ABC Company and to apply different forecasting methods extracted from various sources, in order to identify which methods present the best prediction indexes in relation to the results obtained today by the process adopted by the company.

In addition, a decisive factor for the accomplishment of the case study was the possibility of measuring and comparing the possible gains that would be achieved if the $A B C$ Company adapts its processes to a new model of demand forecasting 
minimizing the lack of products and allowing the minimum possible leftovers, resulting in cost reduction.

\title{
2. METHODOLOGY
}

The case study proposes to analyze specifically the process of forecasting demand in the ABC Company, which acts in the trade of imported PPE. The company is of medium size and is currently one of the market leaders in the protective gloves segment that was recently acquired by a multinational group with more than 13.000 employees distributed in several countries.

According to Gil (1991), the case study is the intensive and deep study of few objects, to obtain broad and specific knowledge of the same; almost impossible task in comparison to other methods.

Already second (YIN, 2001, 32):

\begin{abstract}
"The case study is an empirical investigation that investigates a contemporary phenomenon within its real life context, especially when the boundaries between phenomenon and context are not clearly defined. A research project that involves the Case Study Method deals with at least four issues: what questions to study, what data are relevant, what data to collect, and how to analyze the results. To define the strategy as opposed to the use of experiments, data surveys, historical research, is the consideration of the research question form, the control required on behavioral events and the focus on events. (YIN, 2001, p. 40-77 - translated by the authors)".
\end{abstract}

The data used in the study were extracted from the ERP system and control spreadsheets available on the company network, after analysis identified the importance to have the work based, conducting a literature search using electronic media, books, articles and monographs. Based on the theoretical reference, three products were selected, according to the respective classifications in the ABC curve concept, in order to perform an analysis on items with different demand patterns.

Later, six forecasting methods were applied for each product, selecting the real demand in a period of 12 months, allowing to evaluate which method would achieve the best results if they were adopted in practice. This analysis was elaborated using electronic spreadsheets with data obtained from the company's ERP.

For the application of mathematical models, we used graphs to present the results. Finally, the data obtained were compared to the actual results of the $A B C$ 
Company, in order to identify the impacts generated by applying a forecast model more appropriate to the company's demand.

\section{LITERATURE REVIEW}

\subsection{Logistics}

The term "logistics" has evolved over time, from a simple operational approach to a concept of supply chain management. Logistics involves the whole chain of services needed to interconnect a production point to a consumer center.

Novaes (2007, p.35) defines logistics by adopting the definition of CouncilofSupply Chain Management:

\footnotetext{
"Logistics is the process of efficiently planning, implementing and controlling the flow and storage of products, as well as associated services and information, covering from the point of origin to the point of consumption, in order to meet consumer requirements (translated by the authors)".
}

Considering the logistics relationship with the world and with simpler everyday activities, we can say that logistics is everything that makes us do a job well, avoiding waste, high cost, and innovating besides controlling well what we have.

According to Fleury (2000), one of the most important logistics elements today is Supply Chain Management, it processes the logistics system, which deals with the flow of materials and internal and external information in companies. With the relationship that emerges along the chain, it seeks to ensure its best results in terms of waste reduction and benefit to the logistics service. This makes the logistics stops being a complementary and separate process, to become a complex one that involves a chain of processes that meet a certain demand.

\subsection{Supply Chain}

The definition of the supply chain according to Ballou (2006) is the union of logistic functions repeated several times in the process of converting raw materials into final product, giving a higher added value to the product, being that when the points of origin of materials and the commercial poles are not located in the same region and the process involves several productive stages, the logistics functions are repeated several times from the origin until the delivery of the product to its final destination. 
The elements that make up the supply chain according to Novaes (2007), are the supply of manufacturing, manufacturing, physical distribution, retail, consumption and transportation, which are represented in Figure 1 and are described as the organization that originates the raw material and the industrialization of a certain product to the end customer.

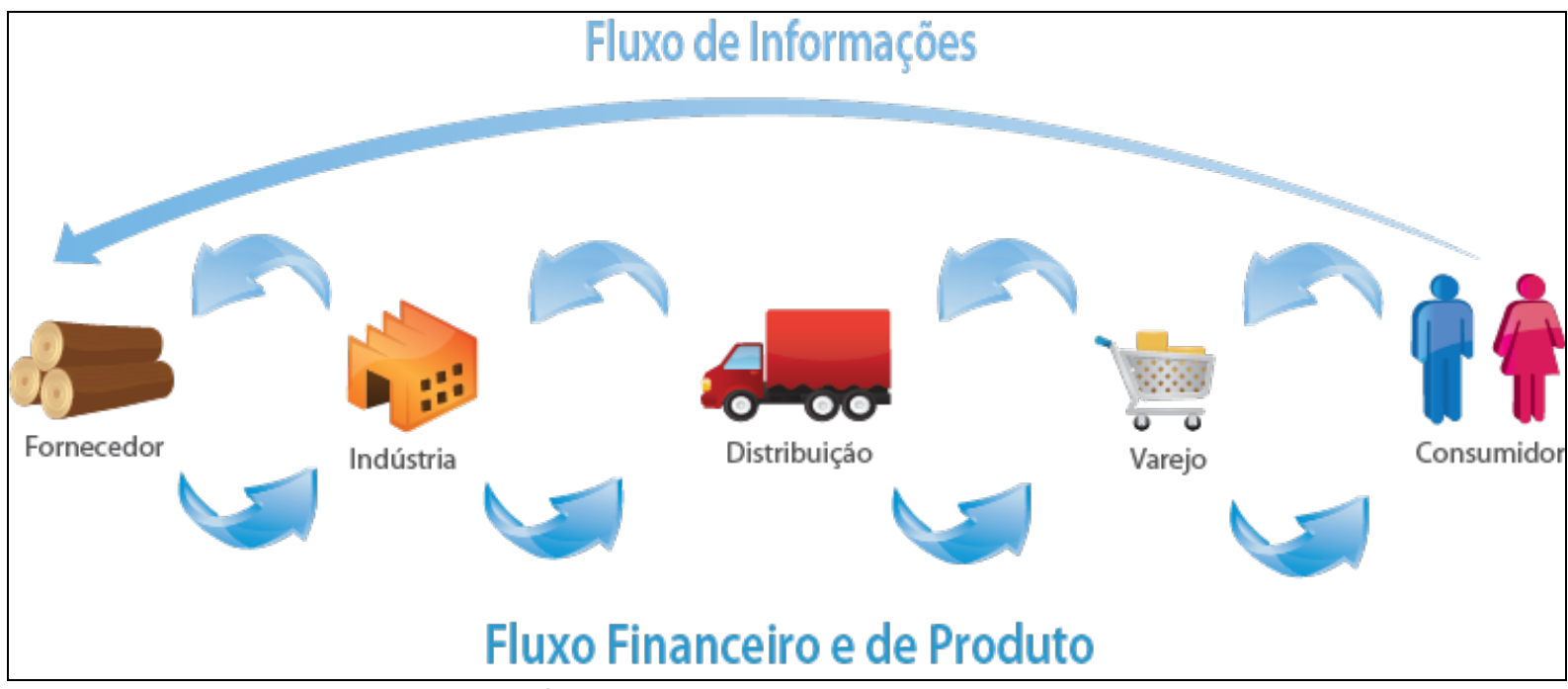

Figure 1: Supply system - production-distribution

Source: Mundo dos negócios, 2016

Therefore, it is understood that the supply chain and its management completely cover all stages involved directly or indirectly in the flow of materials and information from the source of raw material for industrialization to the receipt of the finished product by the consumer. This process not only includes manufacturers and suppliers, but also transport warehouses, retailers and customers themselves.

Supply chain management and planning are fundamental for companies to obtain market competitiveness, achieving greater production efficiency due to a reduction in minimum cycle time and inventory, functional operation, efficient and strategic distribution, and in retail, consequently, it obtains greater customer satisfaction and broad market share.

\subsection{Forecast of Demand}

In recent years, the demand forecasting function has become important due to the influences of a more competitive market. This fact can be proved by the use of this technique in the various departments of organizational management, such as the area of finance, human resources and sales. These predictions are also effective in the operationalization of various aspects of production management, such as 
INDEPENDENT JOURNAL OF MANAGEMENT \& PRODUCTION (IJM\&P)

http://www.ijmp.jor.br

v. 8, n. 5, Special Edition IFLOG 2016

ISSN: 2236-269X

DOI: 10.14807/ijmp.v8i5.595

identifying new business opportunities, anticipating future demands, more efficient production scheduling, and inventory management (SANDERS et al., 2003).

For Diaz and Pires (2003), demand forecasting is a critical phase for a supply chain team, due to the complexity and doubts of their activities. Because of their importance in business, some companies have adopted some alternatives, one of which is to create a specific area for demand management, which, functionally, can be linked to the commercial, industrial, logistics or financial directorate.

For Gurgel (2000), stock management is closely linked to the possibility of estimating the expected consumption of an item in a given future period. The more accurate the demand forecast, the more information the material manager will have to make decisions about what level of inventory to maintain and how much to buy or manufacture to meet the needs of its customers.

According to Bowersox and Closs (2001), there are three types of forecasting techniques: the qualitative, the causal, and the time series. Qualitative techniques use market information and expert opinions on commodities or in trades where products are found to which future demand is to be predicted. A qualitative technique may consider the past or not, when applicable or available.

According to the author, this technique is ideal for situations where there is little availability of historical data and the ability to analyze management. For causal techniques, explanatory or independent variables are used to describe a relation between an important event and its main causes, as it associates historical data of the commodity with one or more variables. The author considers this technique viable in the long-term forecasts.

Techniques based on time series that predict future demand in mathematical models and through statistical data. According to the author, this technique admits that the future is similar to the past, so it considers that existing patterns of demand will persist in the future. However, the applicability of this technique is more coherent when compared to previous ones for short-term forecast planning (BOWERSOX; CLOSS, 2001).

In the case study, which is the main theme of this article, the quantitative technique is used. Quantitative methods use historical data to anticipate demand in future times. The forecast of the future demand promotes the construction of 
mathematical models from the data that describe the change of demand over time. This data set is called the time series (PELLEGRINI; 2000).

According ( ZANELLA 2015, p: 51) :

"Demand forecasts are based on quantitative methods, but also depend on a qualitative analysis of the integrated production planning of each plant, ie, those responsible for each factory evaluate the scenario to also identify the best use of the demand forecast (translated by the authors)".

\subsection{Stock}

The stock can be defined as storage of material resources in a transformation system (SLACK et al., 2007). The main function of inventory is to promote balance between supply and demand. Thus, companies must minimize the total logistical cost of inventories, transportation and order processing according to a given product availability desired by the final customer (CHRISTOPHER; 2011).

Using some indicators can help with this task. Therefore, it is important to identify the various activities relevant to inventory management such aslead-time of resupply generating supplier reliability, demand forecasting, planning, inventory control and costs to maintain inventories.

The main factors that pressure stocks to rise according to Krajewski and Ritzman (2002, p.69) are:

"• Customer service: high inventories reduce the possibility of stock disruption; That is, failure in the availability of an item to satisfy a demand at the time it occurs;

- Order cost: Each time the company places a new order, it incurs the cost of preparing a purchase order from a supplier or a production order to the production unit. Since, for the same item, the cost of placement is independent of the size of the order, the tendency is to make large orders to dilute this cost;

- Cost of transportation: lower transportation costs can be obtained by shipments of complete cargo, which requires an increase in the available inventory for shipment;

- Payment to suppliers: companies can choose to buy larger quantities, both to take advantage of prices on the eve of a discharge and to obtain quantity discounts (translated by the authors)".

The main reason for maintaining low inventories is that they represent an investment, a part of the working capital, on which the company has to pay interest, rather than receiving them. The cost of stock maintenance is the variable cost of keeping the stock at hand and its three components according to Ballou (2001: 75): 
"interest or opportunity cost; Storage and handling costs; Taxes, insurance and losses ".

Stocks can be classified into four types, as cited by Chopra and Meindl (2003, p. 123).

" Cycle Stock: The portion of total stock that varies directly with the size of the purchase or production lot. The size of the lot varies directly according to the time (cycle) between orders;

- Security Stock: To avoid problems of uncertainty in demand, lead time and supply, security stocks are generated. Such inventories ensure that operations will not be interrupted when said problems occur. As demand uncertainty increases, the required level of safety stock increases;

- Stock of anticipation: these are stocks used to absorb predictable variations in demand or supply. Seasonal demand patterns, strike threats, or severe supplier capacity constraints should be smoothed out by anticipation inventories;

- Stock of movement: Inventories are moving from point to point in the supply chain. Movement inventory consists of orders that have already been placed with suppliers, but not yet received (translated by the authors)".

One of the most used concepts in the management of the supply chain for inventory management is the $A B C$ curve, which according to Ballou (2006), the hindrance of any organization is the set of adversities related to each product.

\subsection{Foreign Trade}

According to Dias (2008), international trade is essential for all nations, especially in the era of globalization, because regardless of whether the country is developed or not, its practice contributes to the capital turnaround and growth of the economy.

The importation in Brazil began in the 1990s, when President Fernando Collor de Melo "Era Collor", president who gave progress to modernization in Brazil formulating guidelines and the objectives of foreign trade in its execution, commanded Brazil. Since then, specific norms have been created, with an emphasis on inflation control and the idealization of instruments for importation, the modernization of the Brazilian industrial park and the acquisition of new technologies (LUDOVICO, 2007).

The globalization of the economy makes the exchange of goods and services between countries happen faster, this movement tends to grow due to the need for alliance between developing countries so that they can compete with greater possibilities in the world market (VASQUEZ, 2007). 


\section{CASE STUDY: DEMAND ANALYSIS IN THE IMPORTATION PROCESS FOR THE TRADE OF INDIVIDUAL PROTECTION EQUIPMENT}

The case study refers to the company $A B C$, which operates in the field of PPE, specifically in the trade of gloves and goggles and has 140 direct employees. Founded in 1988, it started as a family-owned business and operated as a resale of steel mesh gloves. Over the years, new products were added and the company followed the evolution of the market. Between 1997 and 2000, it launched its own brand and stopped representing other brands.

Currently $A B C$ is one of the largest in the glove and safety glasses market in Brazil, reaching in recent years an expressive growth rate in sales of more than $20 \%$. Its products are imported from various countries like China, Germany, India, Pakistan, Korea, Taiwan, among others. In 2011, an international group that acts in the distribution of equipment and outsourcing bought the company. This group is, also present in 23 countries and has more than 13.000 employees.

The company $A B C$ is located in the city of Guarulhos, in the neighborhood of CECAP, near the International Airport of São Paulo and the President Dutra Highway, facilitating the logistics and transportation process.

After the acquisition of the company by the multinational group, one of the main guidelines established by the new owner was the need to reduce inventories in order to adapt the company to the standards practiced in the other companies of the group.

This would increase working capital, and minimize the present opportunity costs in the company, generated by high levels of inventories. In this context, it was necessary to evaluate the inventory management and demand analysis process to identify possible failures and adjust the inventory to the plans established by the new company controller.

The company $A B C$ has a varied product line, specialized in the protection of the hands and eyes, focused on the safety of work in various segments such as: agricultural, food, automobile, auto parts, cosmetics, construction, industrial kitchens, electronic, refrigerator, logging, metalworking, mining, cleaning, logistics, chemical, petrochemical, glazing, among others. Among the items listed above, it adopted as a 
INDEPENDENT JOURNAL OF MANAGEMENT \& PRODUCTION (IJM\&P)

http://www.ijmp.jor.br

v. 8, n. 5, Special Edition IFLOG 2016

ISSN: 2236-269X

DOI: 10.14807/ijmp.v8i5.595

market strategy to divide its product line into two: a traditional and more affordable line of products and another line of high performance products with higher benefit.

The organization markets individual protection equipment imported throughout Brazil, through regional distributors and several resellers, as well as directly serving large end customers such as assemblers, mining companies, refrigerator networks and industries of various segments. However, to market this type of product in Brazil, companies must follow some standards, so that all products are certified according to specific federal standard.

\subsection{Marketing}

After being certified, the product is placed in line. In order to generate demand, $A B C$ Company counts on several teams: from the marketing and the development team, that elaborates new products according to the needs of the market, also, counts on specialized technicians in labor safety that make a work of dissemination of the products and offer more attention to the great clients and resales.

Besides these teams, the $A B C$ Company also has an internal team and an external sales team, the internal team being an active and passive Call Center, in which calls are received from customers who wish to buy the products and where employees offer the products to customers. In addition, the external team is composed of commercial representatives dispersed by states.

When a customer makes a first contact, a registration is made in the company's ERP system and a check is made of all information provided by the customer. Because of the policy adopted by the company $A B C$, sales are not made for individuals, only for companies, and if a natural person contacts to buy the products, it is sent to a reseller closer to their region.

Sales orders are received by the internal team directly via telephone or via email containing the purchase order of the customers and are registered in the company's system by the sales assistants. After the order is issued, the customer receives a copy of the order, containing the items, quantities, prices, payment conditions, freight type, carrier, place and date of delivery, for analysis and approval of terms negotiated by the customer. Given this, the sales team only forwards the processes after the confirmation of the customer. 
INDEPENDENT JOURNAL OF MANAGEMENT \& PRODUCTION (IJM\&P)

http://www.ijmp.jor.br

v. 8, n. 5, Special Edition IFLOG 2016

ISSN: 2236-269X

DOI: 10.14807/ijmp.v8i5.595

After the customer has formalized the approval of the order, the seller responsible for the service forwards the request to the administrative sector that coordinates the order processing. In the administrative department, a new request information check is made to verify that the company policy criteria are being met, such as the payment condition that cannot exceed the average term of 42 days, the minimum order value that is $R \$ 800,00$ and the terms of delivery. If any irregularity is found/noticed at this conference, the request is returned to the seller responsible for rectification.

Applications approved for this verification are forwarded to the credit analysis process, which is done by the finance department. To speed up the process, the company's ERP system has a credit analysis module, which automatically approves applications for active customers that have no restrictions, according to criteria defined by the company. However, if the customer has any restrictions, the request is blocked automatically by the system and a credit analyst is in charge of the approval or disapproval of the request. For new clients, the deadline for the credit analysis process is up to five business days.

The next stage in the processing of the orders, after the credit approval, is that the orders return to the administrative sector, which, forwards them to the shipment according to the delivery date. As a rule, for orders received up to 15 hours and do not have credit restrictions, the company $A B C$ guarantees the delivery in 24 hours for the customers of the metropolitan region of São Paulo or on the carriers, for the requests of customers from other regions of the country.

\subsection{Importation}

ABC Company has a strong demand for its product line, which is composed of more than 500 active items that represent the company's monthly billing. Considering the fact that more than $98 \%$ of these products are of foreign origin, managing the purchases efficiently becomes a great challenge due to the longer delivery times and the customs restrictions in Brazil.

The company buys its products from factories distributed by several countries, each of which specializes in one product line. Therefore, the time of a common import process varies according to the origin and the demand of the products, but on average, the purchase requests are sent to the supplier 180 days in advance, from 
the date of creation of the order until the arrival of the Items in the company warehouse.

The purchase process starts with negotiation with the supplier, who in most cases are already long-term partners of the company $A B C$ and generally all terms are already established, only having differences in the price according to the variation of the dollar. After the order is formalized, on average the supplier takes other 45 days to start production and 50 days to complete the lot. Once it is ready, it takes about 70 days to load the shipment, considering the entire time for loading, the transit period and the time for customs clearance.

\subsection{Demand Analysis}

The analysis of the volumes in the company $A B C$ is made through historical consumption data and sales prospects provided by the development department. For this analysis are used daily reports obtained from the company's ERP, as well as spreadsheets to control the duration of inventories and control of orders.

Starting from the sales volumes, a monthly sales plan (projection) based on the average sales of the last four months is created for each item and to complete the composition of the plan, it is also considered the consumption of new clients in the negotiation phase And market growth projections.

The company's stock manager evaluates only the annual and quarterly average to define the sales plan, which is the monthly sales projection that is used as the basis for the creation and control of purchase orders. The follow up of the requests is done through the worksheets of duration.

The employee responsible for inventory management at $A B C$ uses time control sheets, where inventory levels are observed, based on average sales. In these spreadsheets all purchase orders for items are posted, giving you a view of all the available stock in the warehouse, the transit stock, the inventory that is in production and future schedules. In addition, through the duration sheets it is possible to identify possible stock breaks and the order point.

For each supplier or product group there is a spreadsheet of duration, and in some cases control of items that have more than one supplier through a single spreadsheet. All worksheets follow the same pattern and are composed of the product description, product code, sales average (quarter or four-month period), 
sales plan (projection based on sales history and data provided by the development department), stock available for sales (current stock less the quantity in placed orders), duration (available stock divided by the sales plan).

In addition to these fields, (if)?there is a purchase order for the products in the spreadsheet, the fields request (lot number), shipment date, quantity requested (for each item), breakage (if the inventory duration is less than the forecast returns an estimate of how many days the inventory will be discovered) and stock duration after the placed order (quantity ordered divided by the plan plus the current stocking duration).

\subsubsection{Application of Forecast Models}

For the case study, the models of prediction of simple average, moving average, dual moving average, simple exponential damping, Brown method and Holt method were chosen. Each forecasting method was applied over a same period of real demand data supplied by the company $A B C$ in order to analyze what results would be obtained with the application of each method to predict the stock levels needed to supply the demand of the studied period.

In addition, for the analysis of the forecast models, three products were selected according to the $\mathrm{ABC}$ classification, in order to evaluate the applicability of each method and the adjustment levels for both high turnover essential items and low output items. Analysis of the prediction models, three products were selected according to the $A B C$ classification, in order to evaluate the applicability of each method and the adjustment levels for both high turnover items and low output items.

\section{a) Product $\mathrm{A}$}

It was started the evaluation of the data and its forecast with a product of curve $A$, that in the moment of the analysis presented stock of approximately 475.000 pieces, being that its average consumption is of 237.000 pieces, that is, a stock of two months. Chart 1 shows the current $A B C$ sales plan. 


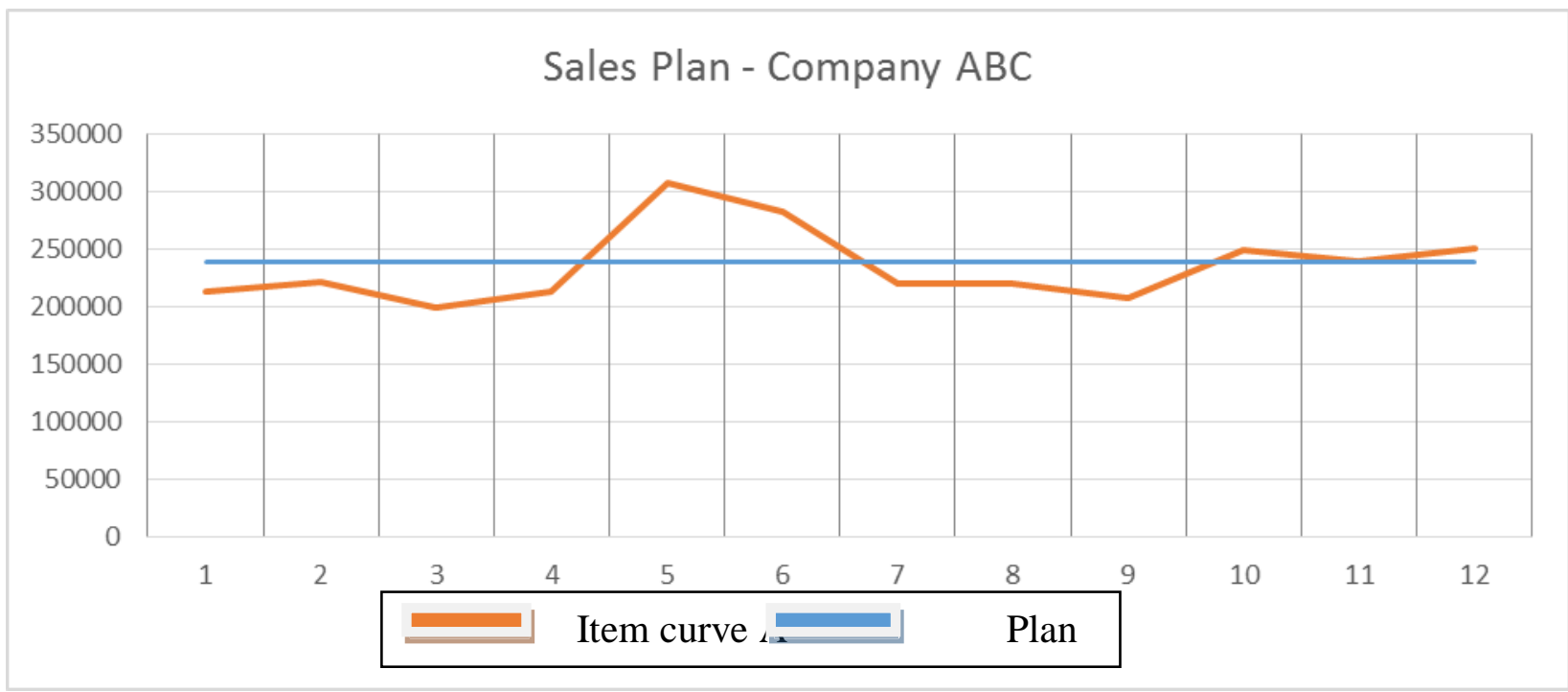

Chart 1: Demand analysis - Product $A$.

Source: Company ABC (2016)

The chart 1 shows that although the plan developed by the company is linear, the forecast was very close to sales for most of the period studied, and a large difference occurred between the plan and actual demand only in the months 5 And 6.

In the forecast by means of the simple average, it should be noticed that there would be enough leftover in the months 02, 03, 07, 08, 09 and missing in the months 05, 06, 10, 11 and 12, and in the 5th and 6th month, there would be an out-of-normal inventory compared to the other months according to chart 2.

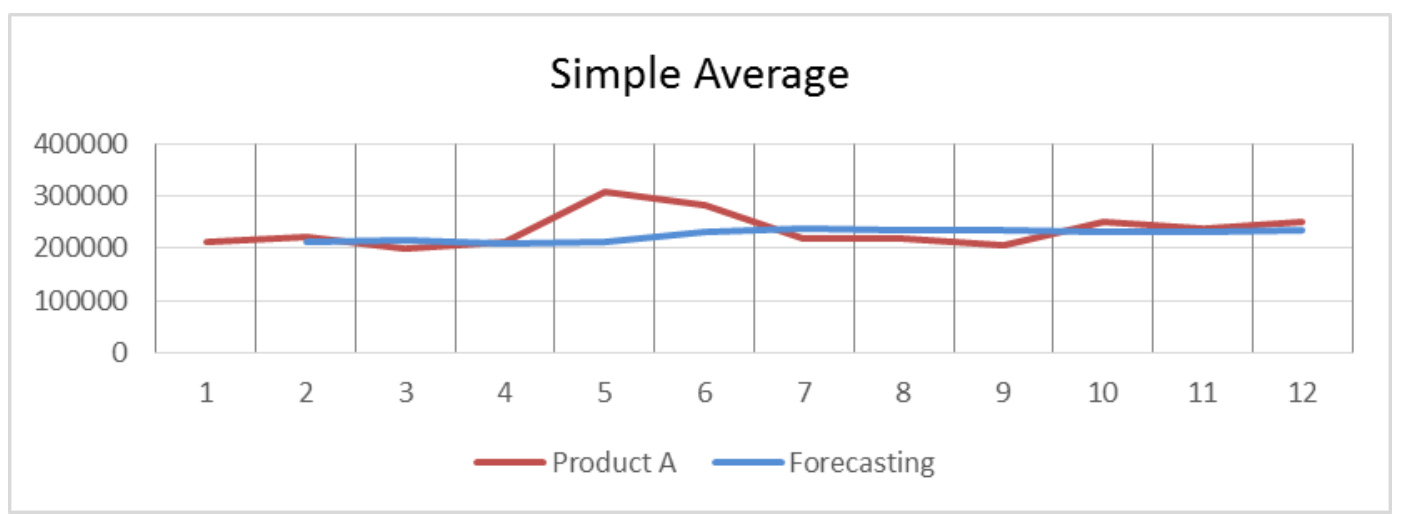

Chart 2: Simple Average - Product Rating A.

Source: Developed by the authors (2016)

Applying the Moving Average Method, it can be observed that in the months 07, 08 and 09, there would be a surplus in the inventory, and in the others, inventory forecasting failure, analyzing chart 3. 
INDEPENDENT JOURNAL OF MANAGEMENT \& PRODUCTION (IJM\&P)

http://www.ijmp.jor.br

v. 8, n. 5, Special Edition IFLOG 2016

ISSN: 2236-269X

DOI: 10.14807/ijmp.v8i5.595

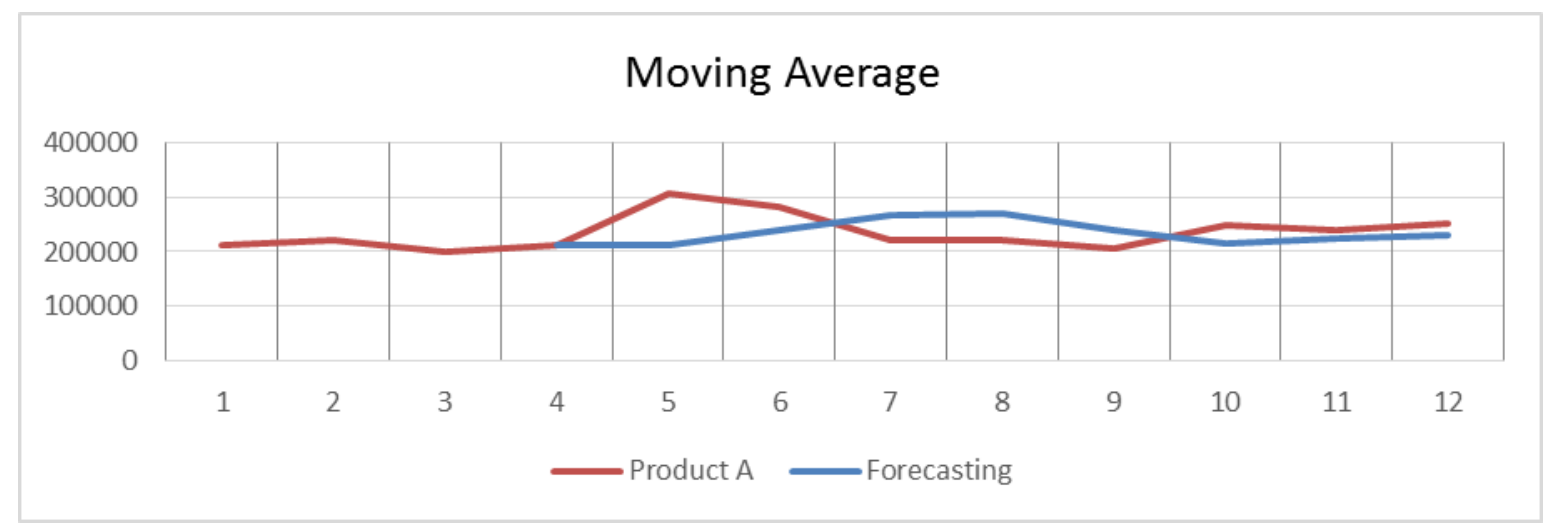

Chart 3: Moving Average - Product Rating A.

Source: Developed by the authors (2016)

According to the method applied in the months 04, 05, lack of products, 6 and 07 would occur surplus, 08, 09, 10 missing again and month 11, 12 balance between forecast and demand analyzing chart 4.

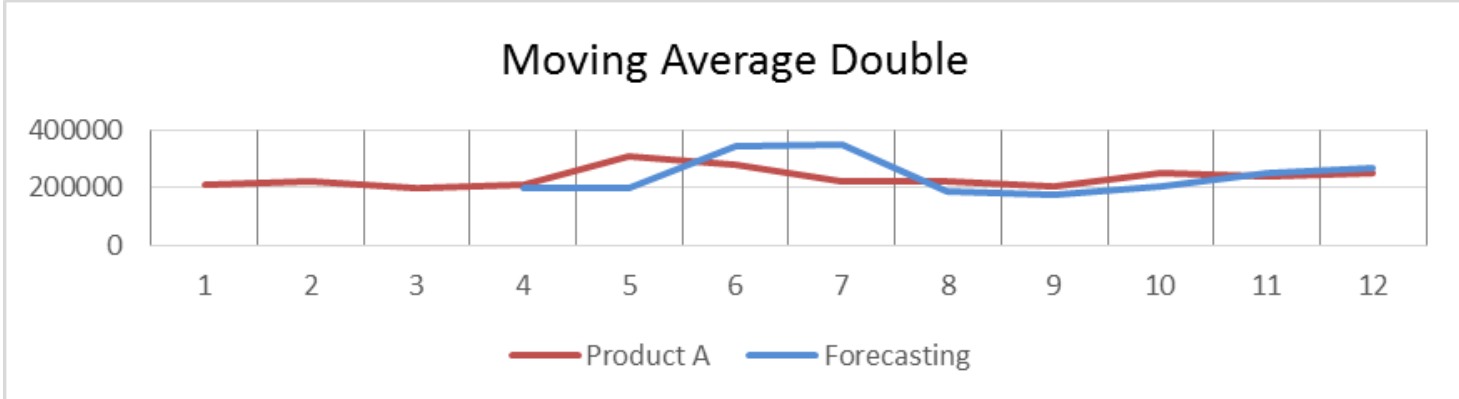

Chart 4: Moving Double Average - Product Rating A. Source: Developed by the authors (2016)

Exponential simple damping presented material surplus in months 03, 07, 08 and 09 with and missing in months 05, 06, 10, 11 and 12, with the largest difference occurring in month 5 of approximately 100000 . According to chart 5.

\section{Simple Exponential}

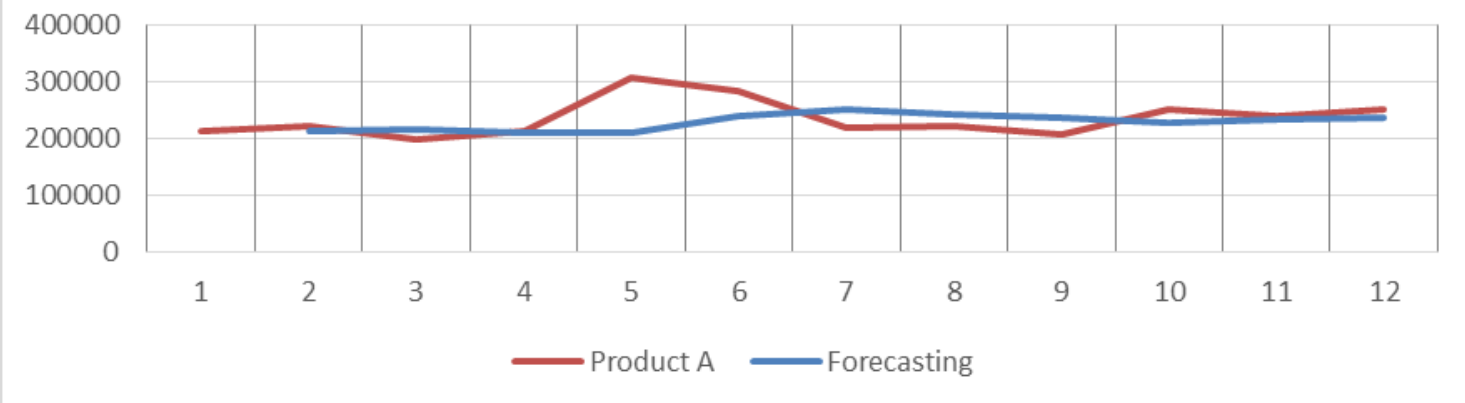

Chart 5: Simple Exponential - Product Rating A.

Source: Developed by the authors (2016) 
With the Brown Method, results are very close to the simple exponential method, but the leftovers level in months 07 and 08 would be larger according to chart 6 .

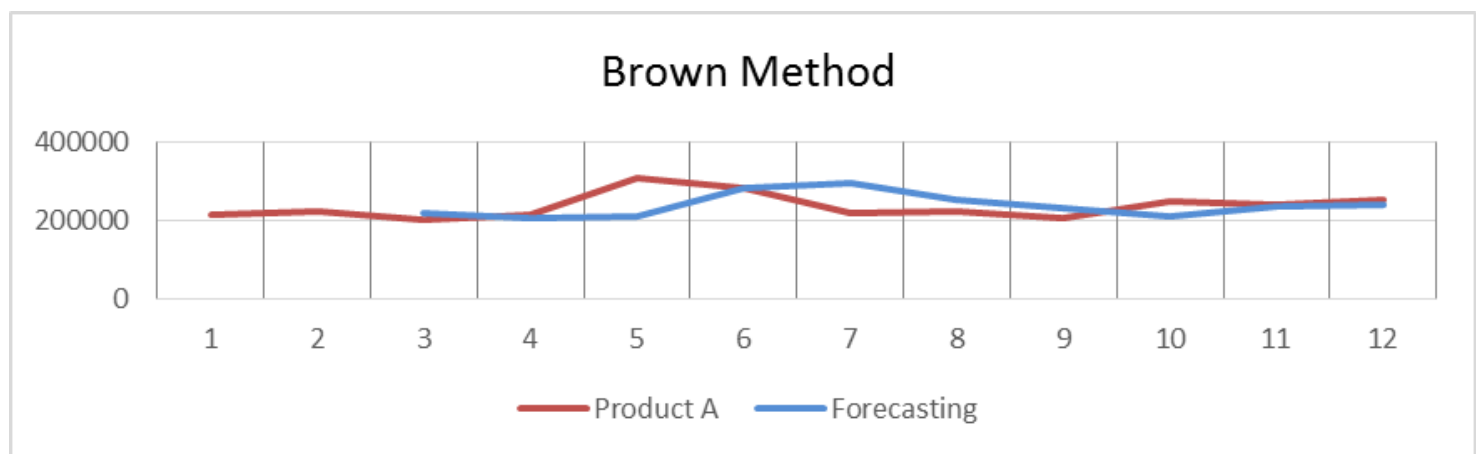

Chart 6: Brown Method - Product Rating A.

Source: Developed by the authors (2016)

The evaluation of the use of the Holt Method shows that in this process the leftovers level was larger compared to the other methods. In the absence of product only in the months 04,05 and 10 - according to chart 7.

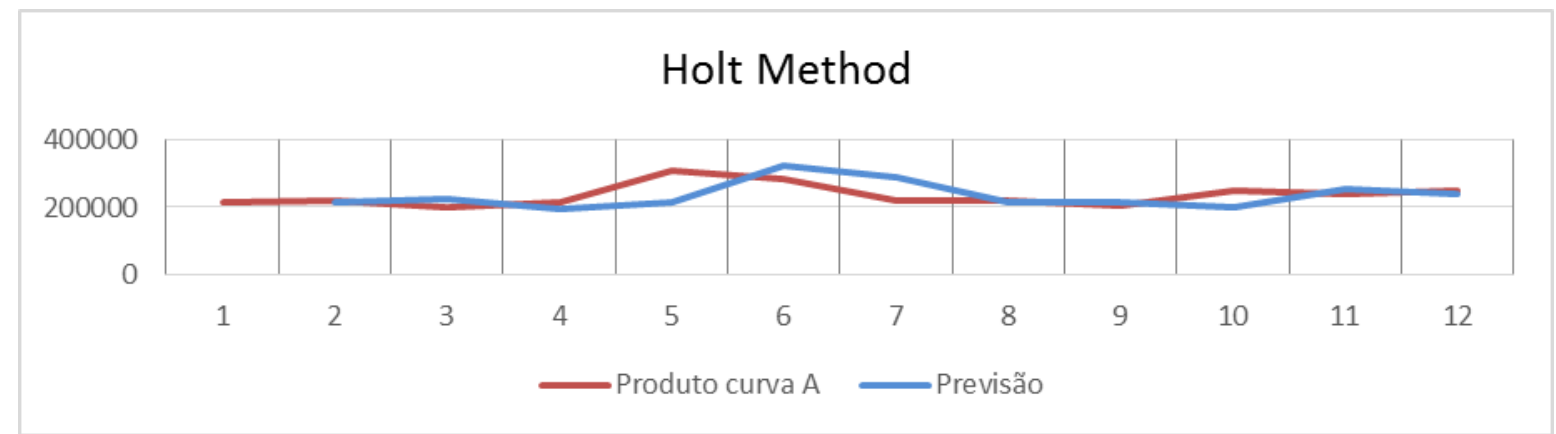

Chart 7: Holt Method - Product Rating A.

Source: Developed by the authors (2016)

\section{b) Product B}

The second item chosen for application of the methods was a Curve B product, which in the period of studies showed average sales of 7,800 pieces and a stock of 44,240 pieces, which would last more than five and a half months. Chart 8 shows the sales and demand analysis plan of $A B C$. 


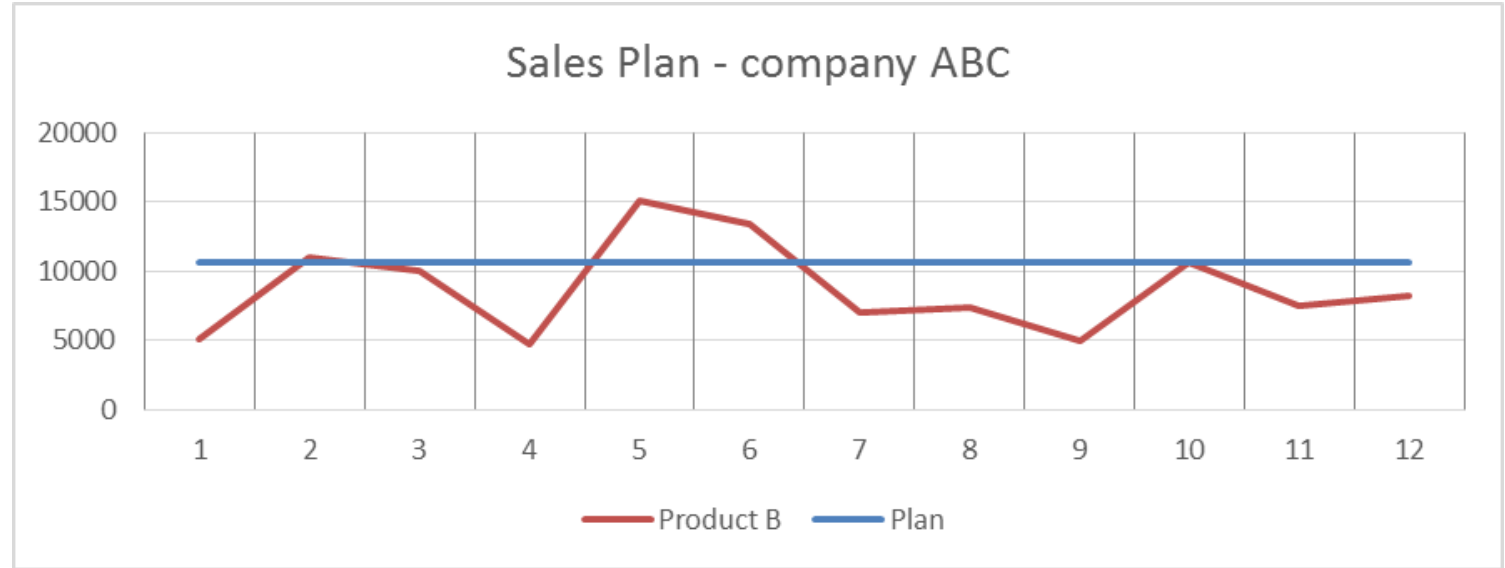

Chart 8: Demand analysis -Product B.

Source: Company ABC (2016)

The chart 8 shows that the company's sales plan was well above demand for most of the period, and demand was only higher in months 5,6 and month 2 by a small difference.

Applying the simple average model, it should be noticed that there would be enough leftovers in months 04, 07, 08, 09, 11 and 12 months 02, 03, 05, 06 and 10, analyzing chart 9.

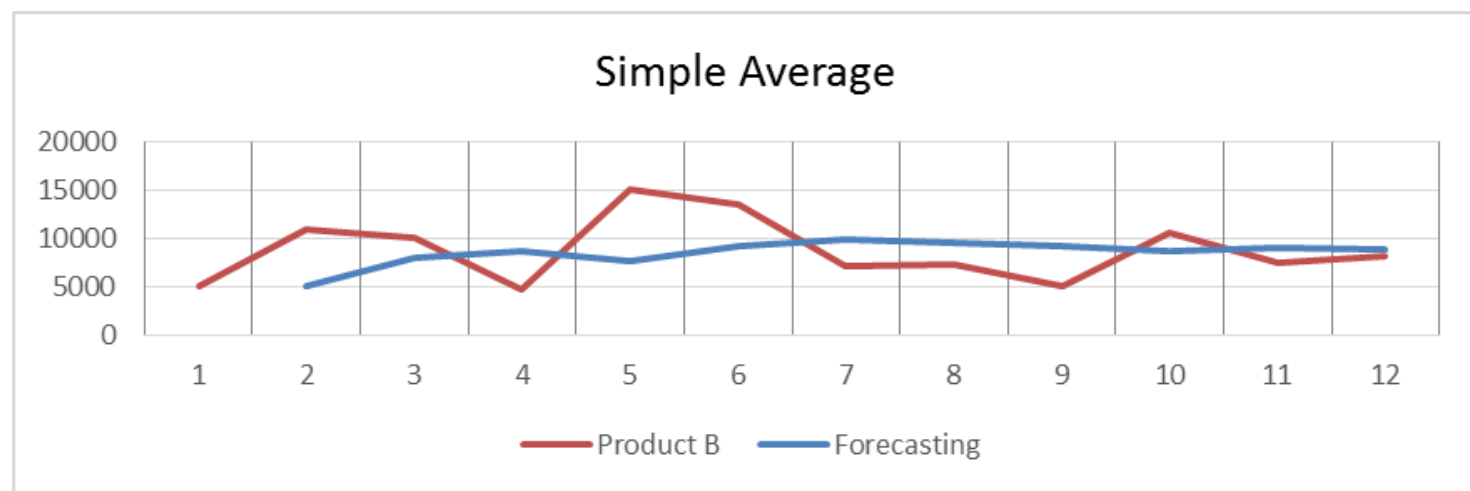

Chart 9: Simple Average-Product Rating B

Source: Developed by the authors (2016)

It can be observed that in the months in chart 10 - of Moving Average - there would be a balance in relation to the lack and surplus of product, since, with the forecast of 08 months, there would be leftover in the months 04, 07, 08 and 09, and there is in the months $05,06,10$ and 12. 


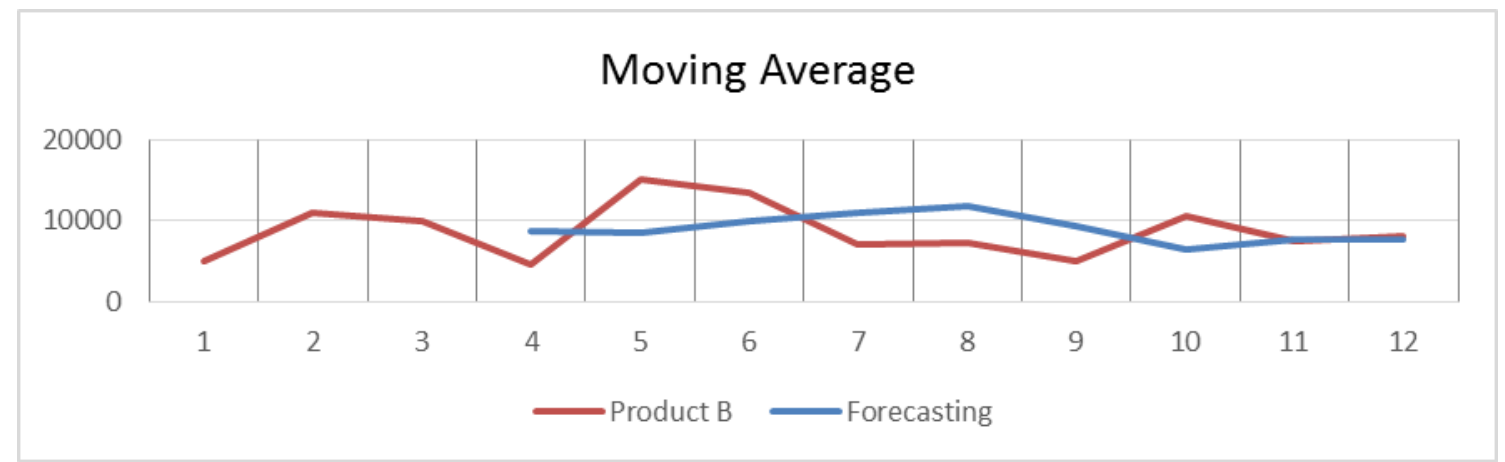

Chart 10: Moving Average-Product Rating B.

Source: Developed by the authors (2016)

According to the method applied in months 05, 08, 09 and 10, there would be a lack of products, 04, 07, 11 and 12, between the forecast and the demand analyzed in chart 11.

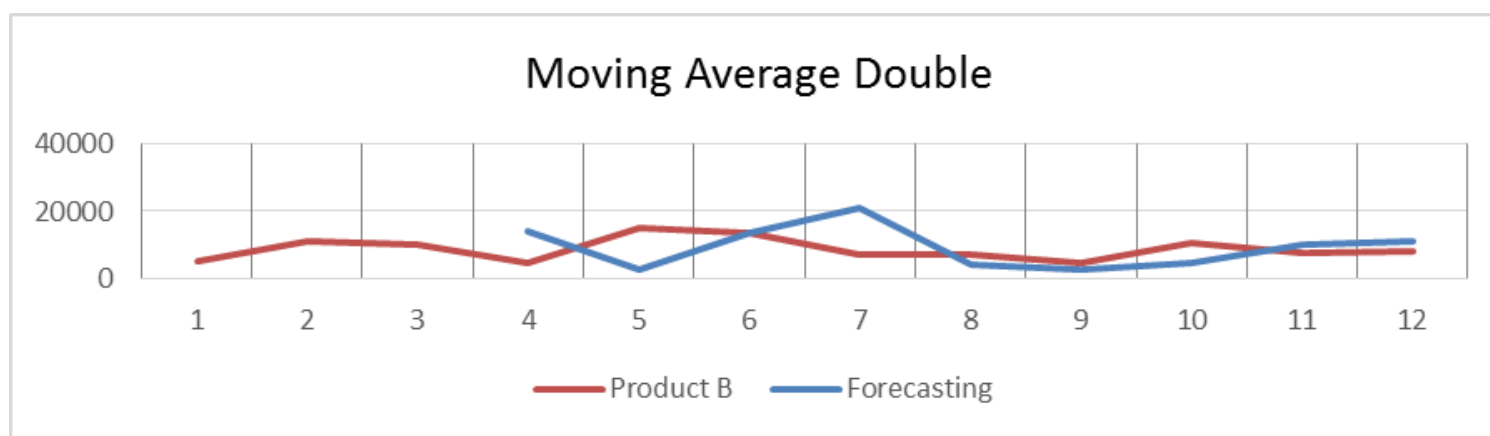

Chart 11: Moving Average Double-Product Rating B.

Source: Developed by the authors (2016)

Exponential simple damping had material leftover in the months 04, 07, 08, 09 and 11 and was lacking it in months 02, 03, 05, 06 and 10, with the largest difference occurring in month 5 approximately 8000 according to chart 12.

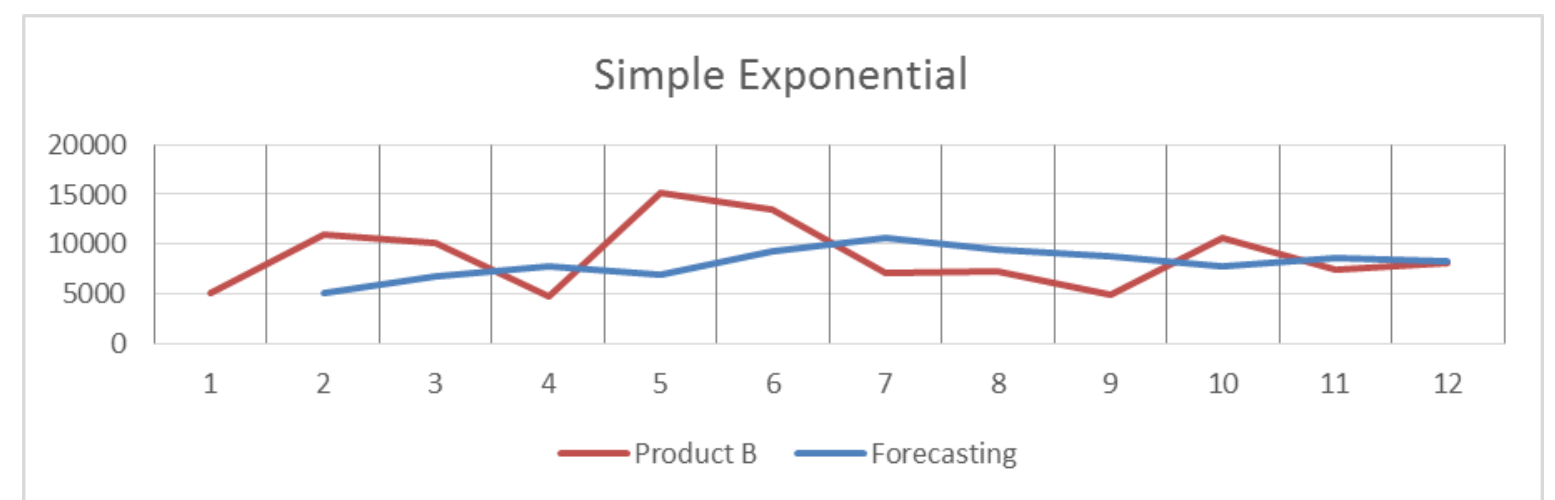

Chart 12: Simple Exponential-Product Rating B.

Source: Developed by the authors (2016) 
INDEPENDENT JOURNAL OF MANAGEMENT \& PRODUCTION (IJM\&P)

http://www.ijmp.jor.br

v. 8, n. 5, Special Edition IFLOG 2016

ISSN: 2236-269X

DOI: 10.14807/ijmp.v8i5.595

In the Brown Method, it was verified that in months 03, 06 and 12 there would be a balance, in months 04, 07, 08, 09 and 11 there would be leftover stock and a large difference of absence in months 05,10, analyzing chart 13.

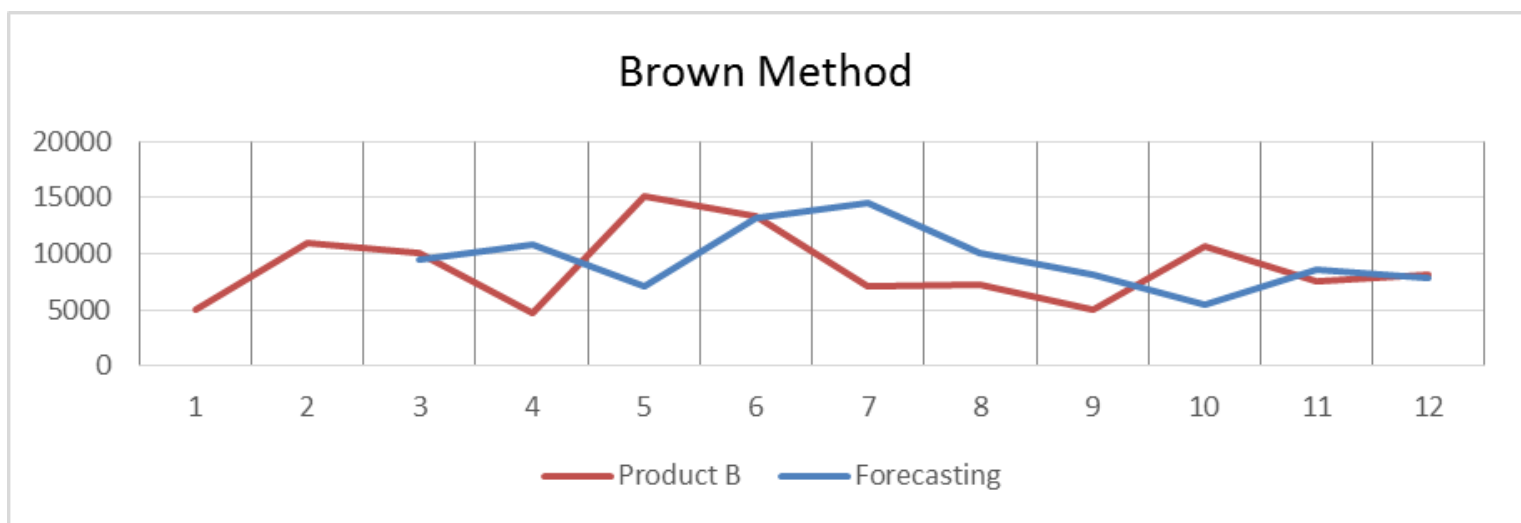

Chart 13: Brown Method-Product Rating B.

Source: Developed by the authors (2016)

Analyzing chart 14, using the Holt Method there would be a discrepancy between forecast and demand in almost every month, except in the months 08, 09 and 12 , causing a lack of efficiency in stock management.

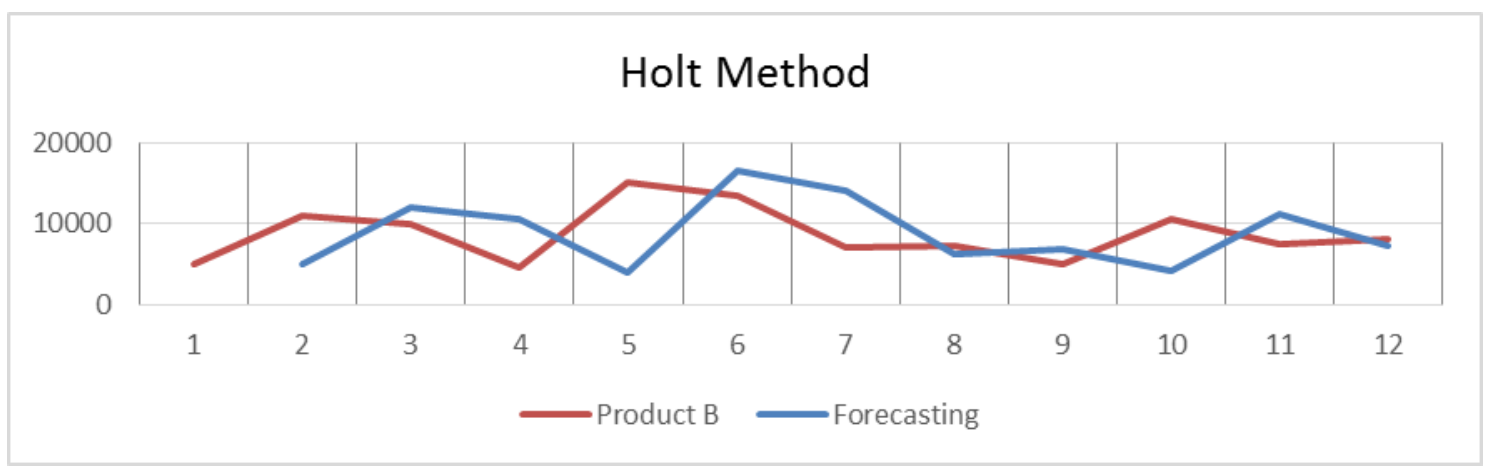

Chart14: Holt Method-Product Rating B.

Source: Developed by the authors (2016)

\section{c) Product C}

To finalize the application of the models, a classification item C was selected as that has a demand with a higher variation index. The stock available at the time of the analysis was 20,839 , but the average sales did not exceed 700 pieces, that is, the stock of the product would last approximately 30 months. Chart 15 shows the current $A B C$ company sales plan. 
INDEPENDENT JOURNAL OF MANAGEMENT \& PRODUCTION (IJM\&P)

http://www.ijmp.jor.br

V. 8, n. 5, Special Edition IFLOG 2016

ISSN: 2236-269X

DOI: 10.14807/ijmp.v8i5.595

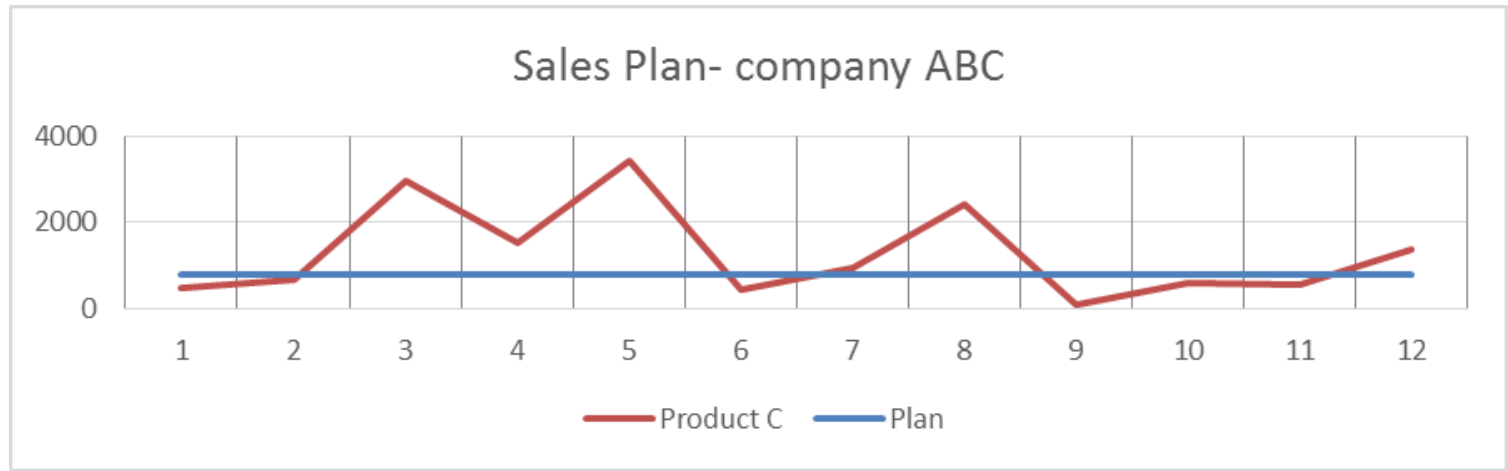

Chart15: Demand analysis - Product Rating C

Source: Developed by the authors (2016)

It is observed that the demand is higher than the sales plan prepared by the company in the half of the months in the studied period, and in the periods that the plan was higher, the difference was small in relation to the demand.

According to chart 16, there would be an imbalance between forecast and demand, making it impossible to control inventory with greater accuracy.

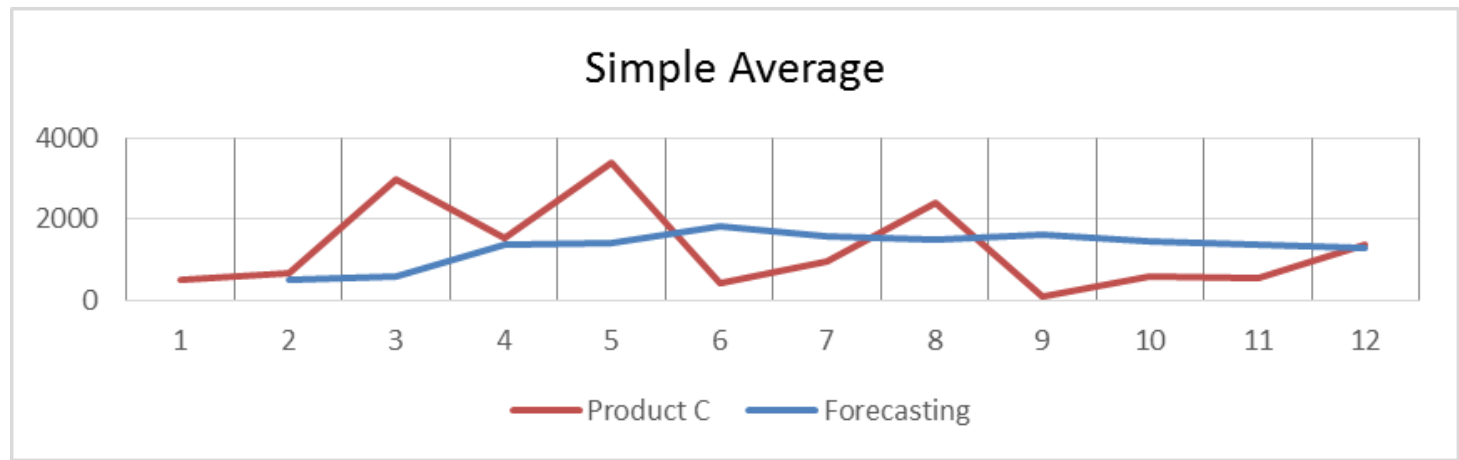

Chart 16: Simple Average-Product Rating C.

Source: Developed by the authors (2016)

It can be seen in chart 17 that the Moving Average would occur with leftovers in the months 06, 07, 09, 10 and 11 and lacked them in the months 04, 05, 08 and 12.

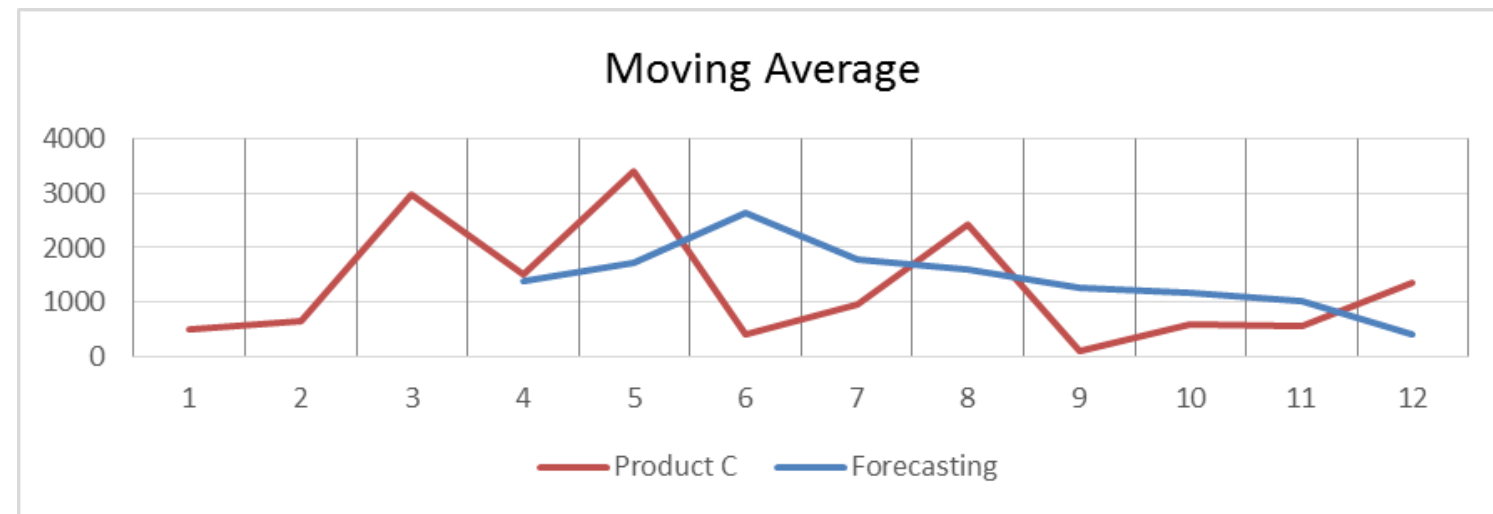

Chart 17: Moving Average-Product Rating C.

Source: Developed by the authors (2016) 
Analyzing chart 18, according to the method applied in the months 05, 08, 11 and 12 , there would be a shortage of products, and there would be a surplus in the months 04, 06 and 09 between forecast and demand.

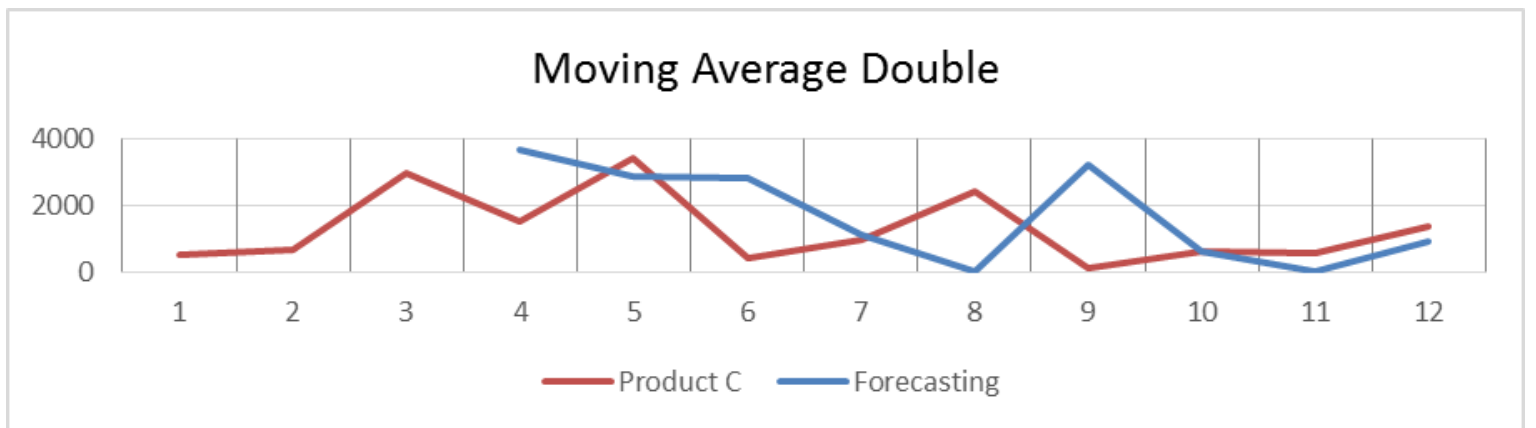

Chart 18: Moving Average Double-Product Rating C. Source: Developed by the authors (2016)

The simple exponential damping showed a surplus of material in months 06 , 07, 09, 10 and 11 and lacked in the months 02, 03, 04, 05, 08 and 12, and the biggest difference would occur in month 5 approximately 2000 , conform the chart 19.

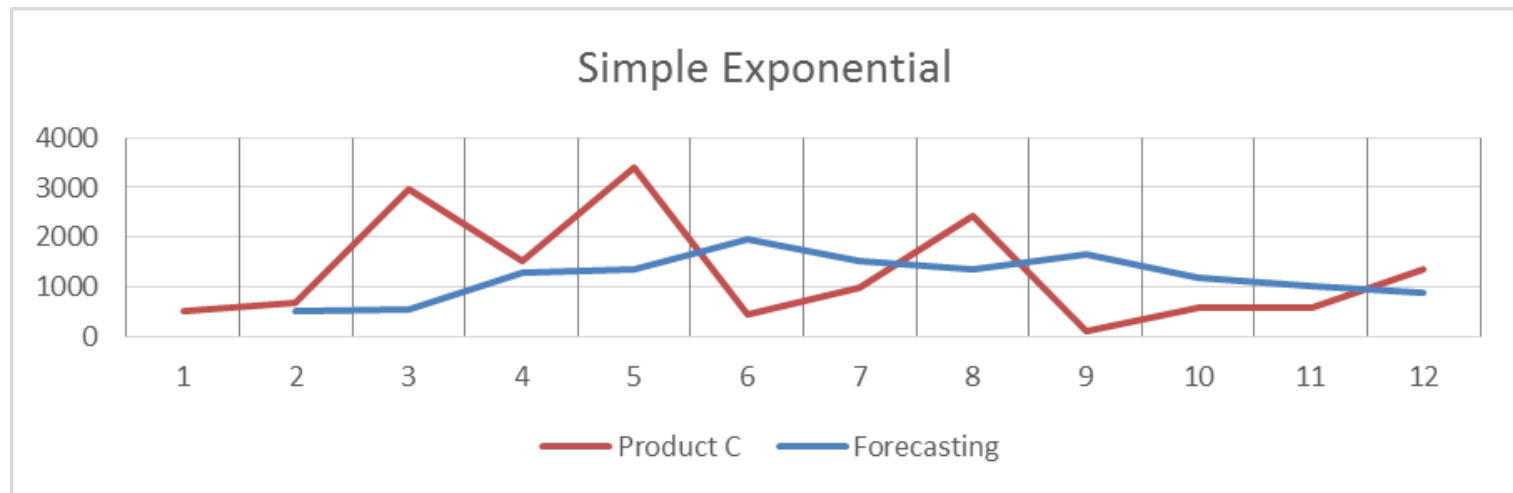

Chart 19: Simple Exponential-Product Rating C.

Source: Developed by the authors (2016)

By the Brown Method it is noticed that in months 10 and 11 there would be a balance, in the months 04, 06, 07, 09 there would be leftover in the stock and great difference to spare in the month 06, according to chart 20. 


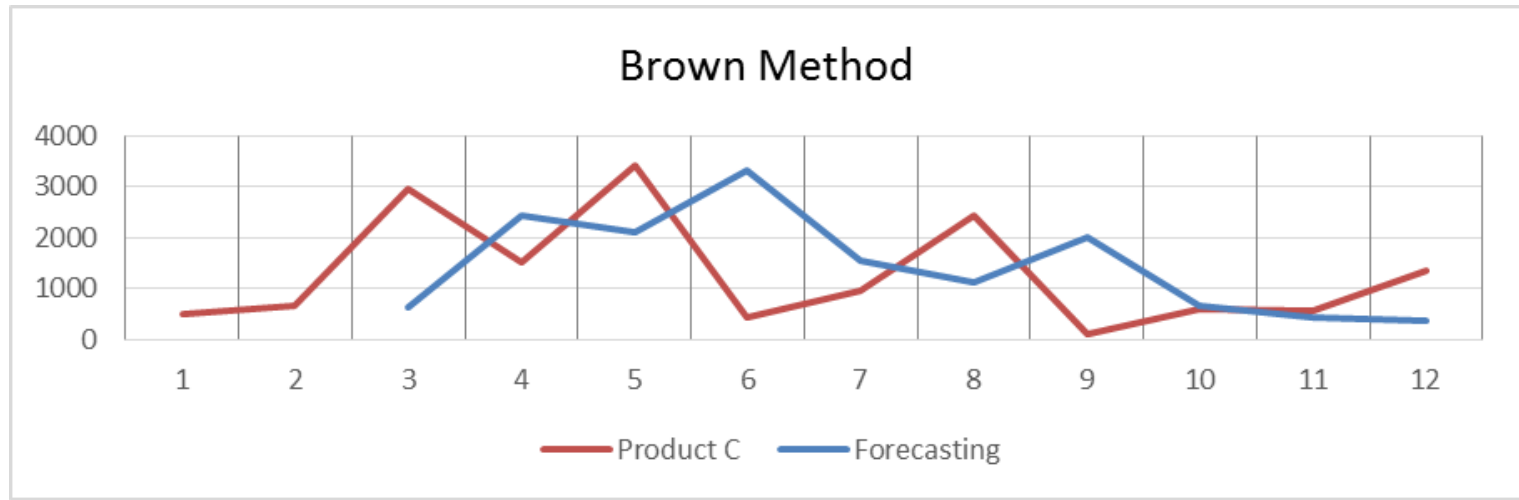

Chart 20: Brown Method-Product Rating C.

Source: Developed by the authors (2016)

Analyzing the chart 21 that demonstrates the Holt Method, it is noticed that there would be a lack in the months 02, 03, 05, 07, 08, 10, 11 and 12, provoking inefficiency in the stock management.

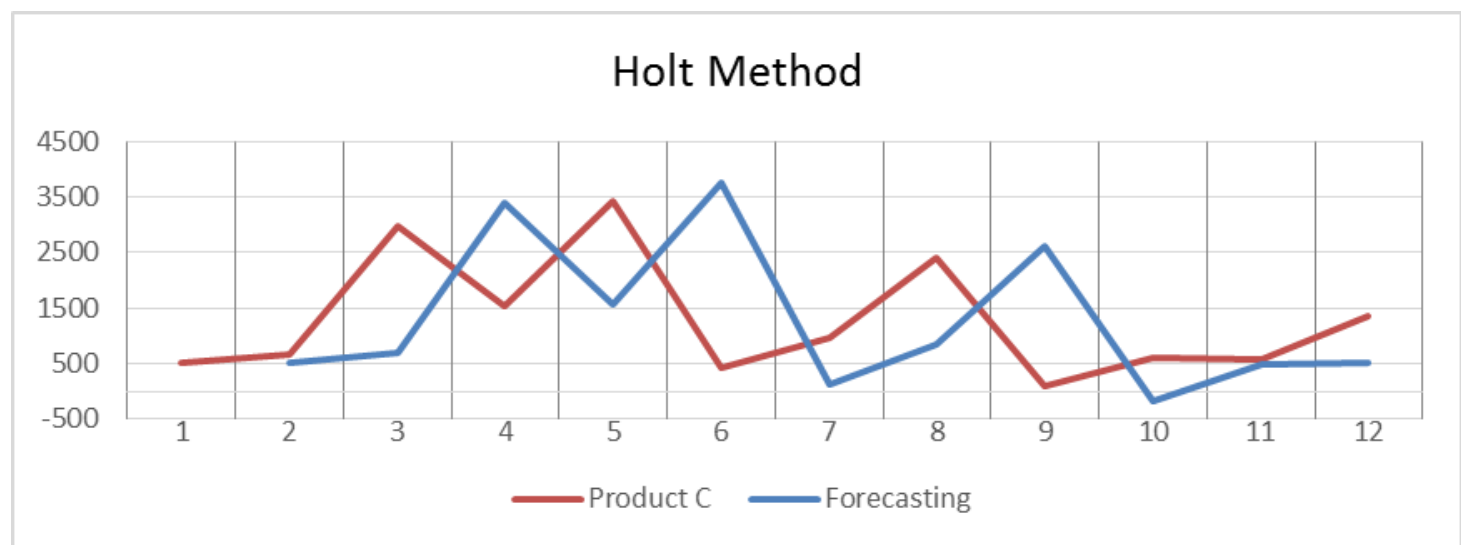

Chart 21: Holt Method-Product Rating C.

Source: Developed by the authors (2016)

After applying the models, a table was created in order to compare the forecasts obtained with the company's current plan and to evaluate which methods would obtain the highest hit rates in relation to the actual demand of the studied period, as shown in table 1. 
ISSN: 2236-269X

DOI: 10.14807/ijmp.v8i5.595

Table 1: Comparison of the results of the application of the forecast models.

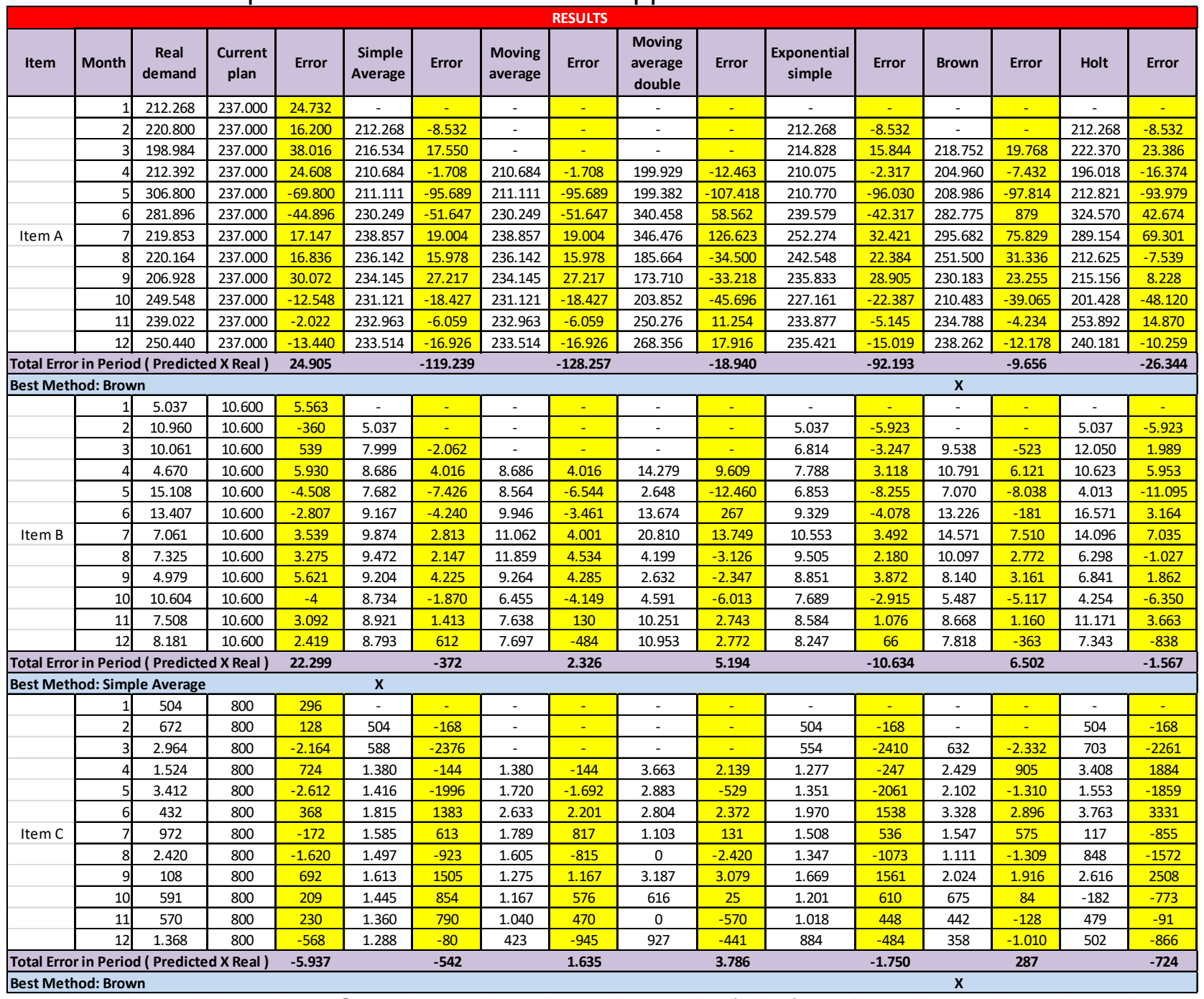

Source: Developed by the authors (2016)

Considering the company's goal, which is to reduce stock shortages and leftovers, it was chosen as the criterion for evaluating the best method, the smallest difference between forecast and actual demand. Thus, the Brown method was more effective for items $A$ and $C$, whereas for item $B$, the method that most approached the actual demand was the Simple Average method.

However, to evaluate the financial impacts at the end of the period, the results of the best forecast models applied to the actual result obtained by $A B C$ were compared, considering the unit cost of each product supplied by the company. Table 2 shows the comparison of values. 
DOI: 10.14807/ijmp.v8i5.595

Table 2: Comparison of values in stock.

\begin{tabular}{|c|c|c|c|c|c|c|c|}
\hline \multirow[b]{2}{*}{ Product } & \multirow{2}{*}{\multicolumn{2}{|c|}{ Unitary Value }} & \multicolumn{2}{|c|}{ Current Plan } & \multicolumn{3}{|c|}{ Best Method } \\
\hline & & & $\begin{array}{l}\text { Stock at the } \\
\text { end of the } \\
\text { period }\end{array}$ & $\begin{array}{c}\text { Total Value in } \\
\text { Stock }\end{array}$ & $\begin{array}{c}\text { Stock at the } \\
\text { end of the } \\
\text { period }\end{array}$ & & $\begin{array}{l}\text { Value in } \\
\text { Stock }\end{array}$ \\
\hline Item A & & 0,80 & 24.905 & $\mathrm{R} \$ 19.924,00$ & -9.656 & $-R \$$ & $7.724,80$ \\
\hline Item B & $\mathrm{R} \$$ & 1,07 & 22.299 & $\mathrm{R} \$ 23.969,91$ & -372 & $-R \$$ & 399,87 \\
\hline Item C & & 2,58 & -5.937 & -R\$ $\quad 5.939,58$ & 287 & $\mathrm{R} \$$ & 741,45 \\
\hline \multicolumn{3}{|c|}{ Total: } & 41.267 & R\$ $37.954,32$ & -9.741 & -R\$ & $7.383,22$ \\
\hline
\end{tabular}

Table 2 shows that, if the method that obtained the best result in the study was applied to each item, $A B C$ would have a stock deficit in relation to demand in the amount of $\mathrm{R} \$ 7,382.38$, but with the current plan, The company obtained leftover stock and tied capital in the amount of $R \$ 28,466.47$. That is, the adequacy of the plan to the method that provided the least variation between stock and demand levels would provide an approximate reduction of $20 \%$ in the general stock levels.

Because of the practicality of the spreadsheet developed for the study, it became possible to carry out a deeper and faster analysis of all the company's products, and it is only necessary the data from previous periods to obtain forecasts and compare the results, assisting the responsible for inventory management.

\section{FINAL CONSIDERATIONS}

According to the work presented, through methods of forecasting demand in the organization, several theoretical methods were studied, in different bibliographic sources.

Considering these methods, six forecasting models were applied for certain products, where it was noticed that each prediction model has a different applicability, and a method that is effective for a given product may not be feasible for another, since according to the study, the lower the demand variation of the item, the applied methods obtained better hit rates, but in cases where the product presented greater differences in demand between the months, the use of some models would not result in satisfactory predictions. 
In addition, to maintain stock levels according to company needs - using the forecasting methods studied - would require an individual approach for each product and create a planning according to the method that yields the best results, Based on historical data and projections of market growth. However, if stock levels are adjusted to indices very close to demand, there may be a shortage of products in the face of any unexpected variation.

Therefore, in order to minimize the lack of products, in addition to studying which model of forecasting is the most reliable for the product, the company would need to define an acceptable safety margin to avoid ruptures and leftovers of stock and, taking these actions, one notices that it is possible to reduce inventory costs, since analyzing the current method used by the company, it was observed that despite the good indexes of correctness - when applied to the products with the biggest difference in sales between the months - the $A B C$ company model generated leftovers from inventory for items with higher turnover, increasing opportunity costs and reducing company liquidity ratios.

\section{REFERENCES}

ARNOLD, J. R. T. (2008) Administração de materiais. Atlas, São Paulo.

BALLOU, R. H. (1993) Logística empresarial: transporte, administração de materiais e distribuição física.São Paulo: Atlas.

BALLOU, R. H. (2006) Gerenciamento da cadeia de suprimentos, logística empresarial. Porto Alegre: Bookman.

BALLOU, R. H. (2001) Gerenciamento da cadeia de suprimentos: planejamento, organização e logística empresarial. 4.ed. Porto Alegre: Bookman.

BERTAGLIA, P. R. (2009) Logística e gerenciamento da cadeia de abastecimento. São Paulo: Saraiva.

BOWERSOX, D. J.; CLOSS, D. J. (2001) Logística empresarial: o processo de integração da cadeia de suprimento. São Paulo: Atlas.

CHOPRA, S.; MEINDL, P. (2003) Gerenciamento da cadeia de suprimentos: estratégia, planejamento e operação.São Paulo: Pearson Prentice Hall.

CHRISTOPHER, M. (2011) Logística e gerenciamento da cadeia de suprimentos. São Paulo: Cengage.

CORRÊA, H. L.; Corrêa, C. A. (2011) Administração de produção e operações manufaturas e serviços: uma abordagem estratégica. São Paulo: Atlas.

CORRÊA, H. L. (2007) Planejamento, Programação e Controle da Produção. 5. ed. São Paulo: Atlas. 
DIAS, M. A. (2008) Administração de Materiais: uma abordagem logística. 5 ed. São Paulo: Atlas.

DIAZ, C. A. P.; PIRES, S. I. R. (2003) Variação da Demanda ao Longo da Cadeia de Suprimentos: O Efeito da Amplificação da Demanda. Ouro Preto (MG), Ed. UFMG.

FLEURY, F.; WANKE, P.; FIGUEIREDO, K. F. (2000) Logística Empresarial: a perspectiva brasileira. São Paulo: Atlas.

FREITAS, M. A. T. (2006) Secretaria de Planejamento da Presidência da República, Fundação Instituto Brasileiro de Geografia e Estatística. Departamento de Divulgação Estatística. Available at: <http://books.google.com.br/>Accessed in: 06/20/2016.

FONSECA L. R. P. (2007) As novas estratégias logísticas. Available at: $<$ http://www. guiadelogistica.com.br>Accessed on: 08/30/2016.

GARCIA, E. S.; REIS, L. M. T. V.; MACHADO, L. R.; FERREIRA, V. J. M. (2006) Gestão de estoques: otimizando a logística e a cadeia de suprimentos. Rio de Janeiro: E-papers serviços editoriais Ltda.

GOMES, C. F. S.; RIBEIRO, P. C. C. (2004) Gestão da cadeia de suprimentos integrada à tecnologia da informação. São Paulo: Pioneira Thomson Learning. GURGEL, F. A. Logística industrial. São Paulo: Atlas, 2000.

KOBAYASHI, S. (2000) Renovação da Logística, Como Definir Estratégias de Distribuição Física Global. São Paulo. Ed. Atlas.

KRAJEWSKI, L. J.; RITZMAN, L. P. (2002) Administração da produção e operações. São Paulo: Pearson Prentice Hall.

KRIEGER, J. S. (2002) Implantação e gestão de custos em empresas de distribuição. Mestrado em Engenharia de Produção da Universidade Federal do Rio Grande do Sul, Porto alegre. Available at: <http://www.lumi.ufrgs.br/> Accessed on: $07 / 12 / 2016$.

LUDOVICO, N. (2007) Logística Internacional: um enfoque em comércio exterior. São Paulo: Saraiva.

POZO, H. (2008) Administração de Recursos Materiais e Patrimoniais. São Paulo: Atlas.

MARQUES, W. L. (2010) Controle de estoques para análise fundamental empresarial. Paraná: Fundação biblioteca nacional.

MARTINS P. G.; LAUGENI F. P. (2003) Administração da Produção. São Paulo: Saraiva.

MARTINS, P. G.; CAMPOS P. R. (2006) Administração de materiais e recursos patrimoniais.São Paulo: Saraiva.

NOVAES, A. G. (2007) Logística e gerenciamento da cadeia de distribuição. Rio de Janeiro: Elsevier.

PELLEGRINI, F. R. (2000) Metodologia para implementação de sistemas de previsão de demanda. Mestrado em Engenharia de Produção - Departamento de Engenharia de Produção e Transportes. Porto Alegre - Universidade Federal do Rio 
DOI: 10.14807/ijmp.v8i5.595

Grande do Sul, 2000. Available at:

<http://www.producao.ufrgs.br/arquivos/publicacoes/> Accessed: 07/12/2016.

RECEITA FEDERAL, Controle aduaneiro. Available at:

$<$ http://www.receita.fazenda.gov.br/manuaisweb/importacao/topicos/conceitos_e_def inicoes/controle_aduaneiro.htm> Accessed on: 08/25/2016.

RODRIGUES, W.; BORTOTO, A. C.; DIAS, R. (2010) Comércio exterior: teoria e gestão. 2. ed. São Paulo: Atlas.

SANDERS, N. R.; MANRODT, K. B. (2003) The efficacy of using judgmental versus quantitative forecasting methods in practice. Omega 31 . Available at: $<$ http://www.books.google.com> Accessed on: 07/22/2016.

SEGRE, G. (2012) Manual prático de Comércio Exterior. 4. ed. São Paulo: Atlas.

SLACK, N.; CHAMBERS, S.; HARLAND, C.; HARRISON, A.; JOHNSTON, R. (2007) Administração de produção. São Paulo, Atlas.

SOUZA, G. P.; SAMOHYL, R. W.; MIRANDA, R. G. (2008) Métodos simplificados de previsão empresarial. Rio de Janeiro: Ciência Moderna.

TUBINO, D. F. (2000) Sistemas de Produção. São Paulo: Bookman.

VAZQUES, J. L. (2007) Comércio Exterior Brasileiro. 8 ed. São Paulo: Atlas.

ZANELLA, C.; VIEIRA, V.; BARICHELLO, R. (2016) Previsão de demanda: um estudo de caso em uma agroindústria de carnes do oeste catarinense. GEPROS.

Gestão da Produção, Operações e Sistemas, Bauru, Ano 11, nº 1, jan-mar, p. 4557. Available At:

$<$ http://revista.feb.unesp.br/index.php/gepros/article/download/1310/701> Accessed on: 09/25/2016. 